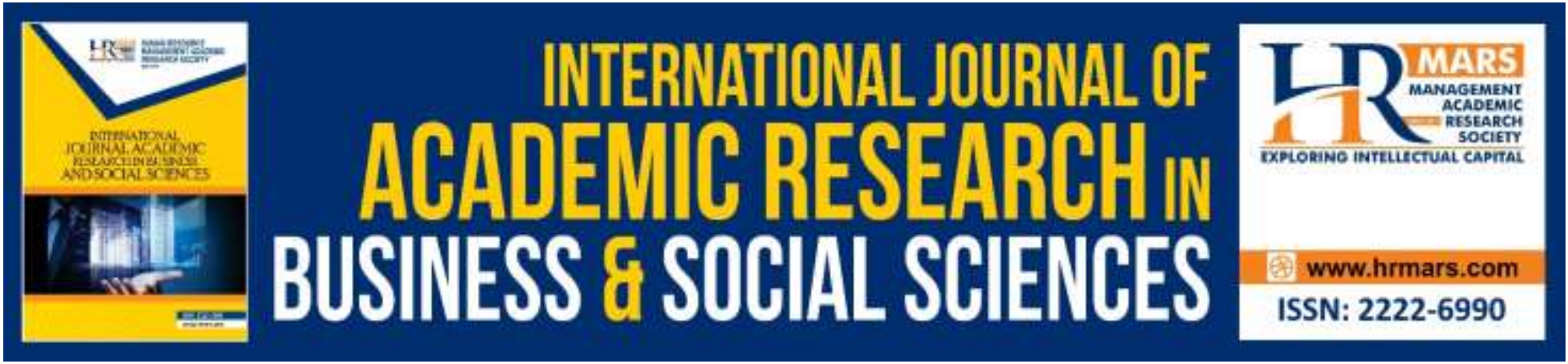

\title{
Managing the Attributes of Pilot Errors in the Process of Redevelopment of Marine Pilot Reliability Index (MPRI): A Systematic Literature Review
}

Tiong Kuong Chiing, Nor Mariah Adam, Omar Faruqi Marzuki, Ellie Yi Lih Teo and Wong Tze Jin

To Link this Article: http://dx.doi.org/10.6007/IJARBSS/v11-i17/11403

DOI:10.6007/IJARBSS/v11-i17/11403

Received: 02 August 2021, Revised: 28 August 2021, Accepted: 23 September 2021

Published Online: 17 October 2021

In-Text Citation: (Chiing et al., 2021)

To Cite this Article: Chiing, T. K., Adam, N. M., Marzuki, O. F., Teo, E. Y. L., \& Jin, W. T. (2021). Managing the Attributes of Pilot Errors in the Process of Redevelopment of Marine Pilot Reliability Index (MPRI): A Systematic Literature Review. International Journal of Academic Research in Business and Social Sciences, 11(17), 217-228.

Copyright: (C) 2021 The Author(s)

Published by Human Resource Management Academic Research Society (www.hrmars.com) This article is published under the Creative Commons Attribution (CC BY 4.0) license. Anyone may reproduce, distribute, translate and create derivative works of this article (for both commercial and non-commercial purposes), subject to full attribution to the original publication and authors. The full terms of this license may be seen

at: http://creativecommons.org/licences/by/4.0/legalcode

Special Issue Title: Empowering Community and Beyond, iRandau, 2021, Pg. 217 - 228

Full Terms \& Conditions of access and use can be found at http://hrmars.com/index.php/pages/detail/publication-ethics 


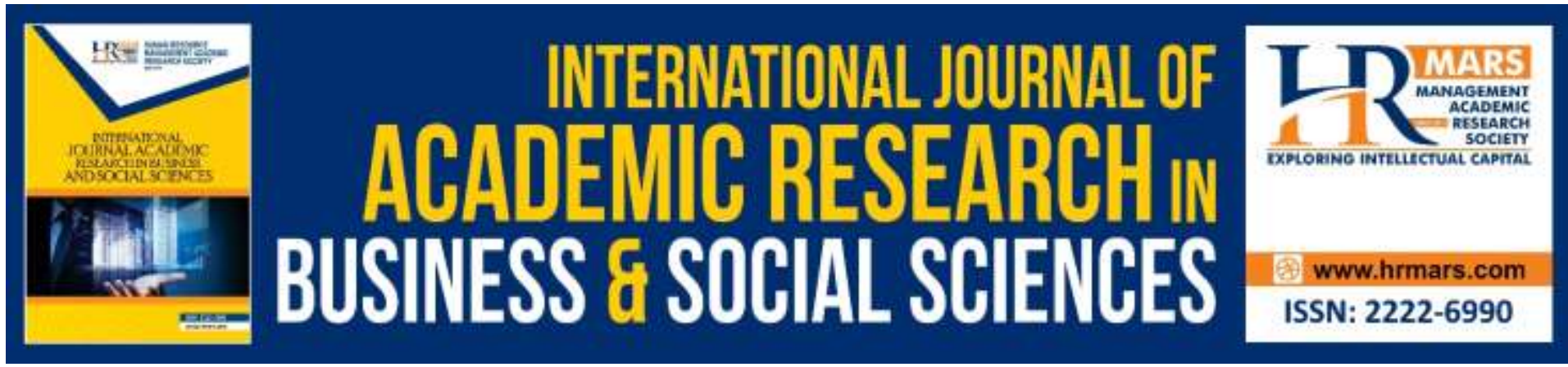

\title{
Managing the Attributes of Pilot Errors in the Process of Redevelopment of Marine Pilot Reliability Index (MPRI): A Systematic Literature Review
}

\author{
Tiong Kuong Chiing ${ }^{1}$, Nor Mariah Adam ${ }^{1,2}$, Omar Faruqi \\ Marzuki $^{1,2}$, Ellie Yi Lih Teo ${ }^{1,2}$ and Wong Tze Jin ${ }^{1}$ \\ ${ }^{1}$ Department of Science and Technology, Faculty of Humanities, Management and Science, \\ Bintulu Sarawak Campus, Universiti Putra Malaysia, Bintulu 97008, Sarawak, Malaysia, \\ ${ }^{2}$ Institut Ekosains Borneo (IEB), Universiti Putra Malaysia, Bintulu 97008, Sarawak, Malaysia \\ Email: tiong@bintuluport.com.my
}

\begin{abstract}
Ships manoeuvring in confined waters of a harbour were required to make used of the services of an experienced pilot equipped with nautical skills to prevent maritime accidents. However, there are not many formal studies on the risks or pilot errors and human reliability of the pilotage. The probability of the ship's collision without a pilot on board is about nine (9) times higher than those engaged a pilot. The objective of this paper is to evaluate the pilot errors, improving pilot reliability and their competencies. This paper reviews and categorizes the literature published about the problems associated with pilot's risk and error in pilotage, to improve the reliability of the pilot. This will cover the review of the recent published literatures on marine pilot's reliability. This paper hope to shine the vital roles of safe pilotage and towage services and determine the efficiency and productivity of any ports. By the end of this research, it is hope that it is possible to improve the generic model to reduce or eliminate all possible human error or pilots' risk and improve the reliability and competencies of pilots using the improved version of Marine Pilot's Reliability Index (MPRI).
\end{abstract}

Keywords: Pilot Errors, Human Reliability, Pilot Reliability, Pilot Competencies, MPRI

\section{Introduction}

Pilots are one of the oldest professions and least known Martin (1977); Barca et al (2003) with written records and legislation in Trinity House, United Kingdom dating back more than six $\left(6^{\text {th }}\right)$ centuries. Pilots play a very important role in ensuring safely and timely entering and leaving of vessels in any ports. Despite being one of the oldest professions, there have been very few formal studies on the risks or pilot errors and human reliability of pilotage. Pilotage and towage play a very critical role in determine efficiency and reliability of any ports of the world. There are not many nautical institutions or universities that are conducting research on pilotage and towage as compared to other professions such as engineering and medical. 
Most maritime accidents occurred near the coastlines, narrow and shallow or navigational channels or within the congested port limits. This is where pilots played very crucial roles in reducing and eliminate human error and improving the human reliability. According to Allianz Global Corporate \& Specialty (AGCS) in its Global Claims, reviewed that $75 \%$ of all the maritime accidents were caused by the human judgment/error and most of it could be avoided or eliminated if there is better towage and more reliable human intervention.

The P\&I Club (Insurance Underwriter), the USA Coast Guards, Marine - Pilots.com and Wagenar et al (1987) have concluded that $75 \%$ to $96 \%$ of all these major accidents costing more than billions of dollars were caused by human error. All these accidents could be avoided if a Formal Safety Assessment (FSA) and proper mitigation measures have been planned and implemented. The existing publications on the FSA by International Maritime Organization (IMO) 2002 is well defined and touching on Human Reliability Analysis (HRA) for shipboard seafarers but this FSA does not cover the pilotage and towage. Atiyah (2019) maps up four (4) key factors (Technical Proficiency, Personal Fatigue, Non-Technical Skills and Fitness \& Strength) to derive the Pilot's Reliability, but he failed to focus on Risk Assessment or Managements. The human error resulted in billions of dollars in claims despite the fact that the vessels were piloted. The IMO's guidelines on FSA and HRA does not incorporate or cover the pilotage and towage. Similarly, the MPRI also failed to focus on pilotage risk assessment and mitigation. Therefore, it is paramount to conduct a proper formal safety assessment and to eliminate all possible human error and improve the human reliability rate of pilotage services in any ports.

This study aims to improvise the MPRI by use empirical data available and to determine the best forecasted solution in providing zero tolerant pilotage services especially in determining the risk and improving the competency of pilots by using Qualitative or Quantitative Method Analysis. By the end of this research, it is hoped that it will be possible to improve the Generic Model to reduce or eliminate all possible human error or pilots' risk and improve the reliability and competency of pilots using the improved version of Marine Pilot's Reliability Index (MPRI).

\section{Literature Review}

Marine pilot and pilotage provide an essential service, but little understood by the global industries. The pilots can be public servants or working for the government, a union/association or as a private entity. Their main responsibilities are to ensure the safety of navigation within ports; thereby protecting port infrastructures, local marine and littoral environments, the safety of those living and working within the ports and its waterways. It is also their job to ensure and enhance the efficiency of ports.

Statistics show that most marine accidents are due to human error (EMSA, 2015; Akyuz, 2015a; Corovic and Djurovic, 2013). Any mistake that a pilot makes may result loss of life, loss of property, closure of port, loss of reputation and affect the stock market. Any mishandling of a vessel can have catastrophic consequences such as fire and explosion or damage to the environment. The limited number of literature reviews or journals on the challenges of pilotage has triggered the author to conduct more research on this topic.

IMO has promulgated the FSA Methodology, and this has been recognized as a structured and systematic framework for risk assessment and control in maritime transportation-related industries. One of the objectives of FSA is to find the most cost-effective solution for risk reduction. Although being widely utilized (e.g., Kontovas and Psaraftis, 2009; Psarros et al., 2010), some studies have shown that FSA still has some drawbacks, such as not being able to 
give an overall picture of risk (Montewka et al., 2014), not being able to measure the risk precisely (Merrick and Van Dorp, 2006), and its lack of reliability and validity (Goerlandt and Kujala, 2014). This methodology however does not touch on the most important part of the supply chain in the maritime transportations - the Pilotage.

It is crucial to have a reliable pilot (Atiyah, 2019) in his study on Marine Pilot Reliability in uncertain environments has used Delphi Technique Approach and Fuzzy Evidence Reasoning (FER) to derive the Marine Pilots' Reliability Index (MPRI).

\section{Pilot/Human Error}

A record of 6091 major accident claims (Over USD 1,000,000/case) associated with all classes of merchant ships conducted over a period of 15 years by UK P\&I Club revealed that $62 \%$ Rothblum (2000) of the claims are attributed by human error. Dr. Anita M. Rothblum of USA Coast Guard has concluded that about $75-96 \%$ of the marine casualties are caused either partly or directly by human error. Her studies shown that human error contributed:

- $84-88 \%$ of tanker accident

- $79 \%$ of the towing vessel grounding

- $89-96 \%$ of collision

- $75 \%$ of allision

- $\quad 75 \%$ of fire and explosions

From the various literature reviews, we have the following findings and conclusions on the main pilot's error.

A Dutch study by Wagenaar and Groeneweg (1987) of 100 marine casualties found that human error contributed to $96-100$ accidents. In 93 cases of the total accidents, multiple human errors were made. Based on their studies, there are many human factors contributing directly or indirectly to the Human Errors. The human factors may include but not limited to poor communication; fatigue; poor automated design; poor general technical knowledge; poor general knowledge; poor maintenance; decision based on inadequate information; faulty policies; malpractices; wrong or poor standard; poor knowledge of one's ship systems; hazardous environment and cultural awareness.

The P\&I Club (World Leading Insurance Underwriter) had summarized the marine claims that involved vessels under pilotage from 1999 to 2019, a total of 1,046 incidents with a total claim in excess of USD 1.82 billion. The types of accidents classified by Insurance companies include grounding; stranding; foundering; flooding; collision; allision; explosion; fire; reduction or loss of a vessel's power or steering capabilities; failures or occurrences, regardless of cause, which impair any aspect of a vessel's operation, components, or cargo; vessel's seaworthiness, efficiency, or fitness for service or route and any incident involving significant harm to the environment.

Mullai \& Paulsson (2011) conducted comprehensive studies and analysis on the marine accidents have classified the main categories of marine accidents as collision; contact; grounding; fire; explosion; machinery breakdown; listing; capsizing; human effects and spill. Table 1 summarize all the three (3) major studies on various types of the marine accidents. Each type of accident could not detach from involvement of Human/Pilot Error. 
Table 1: Major studies on various types of marine accidents

\begin{tabular}{|c|c|c|}
\hline $\begin{array}{r}\text { Wagenaar and } \\
\text { Groeneweg, } 1987\end{array}$ & P\&I Club 1999 - 2019 & $\begin{array}{r}\text { Arben Mullai \& Ulf } \\
\text { Paulsson, } 2011\end{array}$ \\
\hline $\begin{aligned} & \text { i. } \text { poor communication } \\
& \text { ii. } \text { fatigue } \\
& \text { iii. } \text { poor automated } \\
& \text { design } \\
& \text { iv. } \text { poor general } \\
& \text { technical knowledge } \\
& \text { v. } \text { poor maintenance } \\
& \text { vi. } \text { decision based on } \\
& \text { inadequate } \\
& \text { information. } \\
& \text { vii. } \text { faulty policies } \\
& \text { iiii. } \text { malpractices } \\
& \text { ix. } \text { wrong or poor } \\
& \text { standard } \\
& \text { x. } \text { poor knowledge of } \\
& \text { own ship systems } \\
& \text { xi. } \text { hazardous } \\
& \text { environment } \\
& \text { xii. } \text { cultural awareness }\end{aligned}$ & $\begin{array}{l}\text { - } \text { grounding } \\
\text { - stranding } \\
\text { - foundering } \\
\text { - collision } \\
\text { - allision } \\
\text { - explosion } \\
\text { - fire } \\
\text { - reduction or loss of a vessel's } \\
\text { power or steering capabilities } \\
\text { - failures or occurrences, } \\
\text { regardless of cause, which } \\
\text { impair any aspect of a vessel's } \\
\text { operation, components, or } \\
\text { cargo } \\
\text { - vessel's seaworthiness, } \\
\text { efficiency, or fitness for service } \\
\text { or route } \\
\text { - Any incident involving } \\
\text { significant harm to the } \\
\text { environment }\end{array}$ & $\begin{array}{l}\text { a) collision, } \\
\text { b) contact, } \\
\text { c) grounding, } \\
\text { d) fire, } \\
\text { e) explosion, } \\
\text { f) machinery } \\
\text { breakdown, } \\
\text { g) listing, } \\
\text { h) capsizing, } \\
\text { i) human effects, } \\
\text { j) spill, }\end{array}$ \\
\hline
\end{tabular}

Maritime accidents result in the loss of human lives, loss of property and pollution. The average volatility in number and severity of incidents/accidents is about 52 cases yearly or equal to once every week (Marine-Pilots.com/article/145196, 2020).

Without compulsory or voluntary pilotage services, one can imagine the figure on claims. The average claim per incident is about USD 1.74 Million. On incidents/accidents involving vessels with pilots for the last 20 years (1999-2019) Marine - Pilot.com has reported and summarized the following four (4) main categories of accidents:

a) Allision/Contact with Fixed or Floating Objects (FFO),

b) Collision,

c) Grounding, and

d) Navigation or its movement caused.

The Silent Heroes - the pilots, who have reduced the risk and contend the damages to minimum level. Pilots are decisions, actions or inaction by a pilot of a vessel determined to be a cause or contributing factor in an accident or incident. Pilot Errors can be a mistake, oversight, lapse in judgement, lack of training, loss of situational awareness, or failure to exercise due diligence by pilots during the performance of their duties. A broader view of how "human factors" fit into a system is now considered standard practice by accident investigators when examining the chain of events that led to an accident. 


\section{Human Reliability or Pilot Reliability}

Over the last 70 years or after the Second World War, there is a great improvement on ship design and reliability of the ship systems to reduce casualties and increasing efficiencies and productivity. We have seen great improvement on hydrodynamic hull designs, stability systems, propulsion and navigational equipment, cargo compartment or storage system, firefighting system and communication system. However, the human involvement and human error are still high. Human error costs the maritime industry USD 541 million per year as per United Kingdom Protection and Indemnity Club (UK P\&I Club).

Pilotage is an indispensable part of the world shipping and port services. Pilot reliability will determine the efficiency and turnaround of any port. The professionalism and competency will determine pilot reliability. The introduction of FSA and HRA by the International Maritime Organization is one the greatest positive movement to ensure Pilotage Safety Management Policy (PSM). These FSA and HRA can be applied to determine and management the Pilotage Risk.

\section{The Pilot's Competencies}

To have a proper Academic Degree in Maritime Pilotage is still uphill task. The entire system of training and recruiting of Pilots is not unified, it varies from country to country. The reason is simple; there isn't any Institution/Academy/University that is offering Academic/Professional Degree in Maritime Pilotage. At the same time, it is rather hard to gather experienced pilots as well as trainee pilots to undergo 1 to 4 years of studies together as the local requirements and policies are not standardized throughout the world and it always varies from port to another ports.

The introduction of Continuous Professional Development (CPD), mandatory usage of Ship Handling Simulator. And acquiring of new technologies and new knowledge will ensure the improvement of pilot competency. With the continuous improvement and development in pilots' competencies will definitely able to reduce possibility of pilots making error.

\section{Marine Pilot's Reliability Index (MPRI)}

Atiyah et al (2019) of King Abdul Aziz University, Saudi Arabia together with Liverpool John Moores University, UK and Maritime Engineering and Technical Higher College of Technology, Abu Dhabi have conducted comprehensive studies on pilot's reliability index and had created a Generic Model for Pilot Reliability. They named it Marine Pilot's Reliability Index (MPRI).

Atiyah referred to the IMO Resolution A. 960 in the pilot's competency and training. He referred to American Bureau of Shipping (ABS) and summarized the essential factors for pilot's reliability as follow:

1. Knowledge, skills and abilities shaped through an individual 's basic knowledge, general training and experience.

2. Maritime-specific training and abilities such as certificates, licensees and other maritime related skills

3. Physical characteristics of an operator such as stature, shoulder breadth, height, functional reach, overhead reach and weight

4. Physical strength and personal capacities and limitations (such as resistance to freedom from fatigue), visual ability, physical fitness and strength, acute or chronic illness, and substance dependency

5. Physical and mental characteristic (such as individual risk perception), risk tolerance and resistance 
Using the above shaping factors, they identified and classified the main four (4) factors as follow:
(a) Technical Proficiency
(b) Personal Fatigue
(c) Non-Technical Skill
(d) Fitness \& Strength

Their research failed to use the risk management that has been identified by IMO's FSA. From the literature review, it is clear that majority of the accidents were caused by human error. Therefore, it is possible to eliminate all risk if there is formal risk assessment been conducted. Hence, it is an opportunity to further improve on their generic model on marine pilot's reliability.

\section{Pilotage Risk Identification and Management}

According to Aven (2016), the study of risk analysis as a scientific field started about 30 to 40 years ago, hence it is a relative new discipline. To reveal the holistic issues and future perspectives on pilotage safety, comprehensive and systematic literature review of current state-of-the-art research on application of risk identification and analysis are increasingly becoming important.

\section{Pilotage Risk Identification and Risk Ranking}

The risk assessment of ship pilotage is an important method to reduce pilotage risk and avoid safety accidents(Hong-Bin, 2018). Risk analysis management is the process of identifying, assessing and controlling threats to an organization's capital and earnings. These threats, or risks, could stem from a wide variety of sources, including financial uncertainty, legal liabilities, strategic management errors, accidents and natural disasters.

The five steps in risk management process:

Step 1: $\quad$ Identify the Risk

Step 2: $\quad$ Analyse the Risk

Step 3: $\quad$ Evaluate or Rank the Risk

Step 4: $\quad$ Treat the Risk

Step 5: $\quad$ Eliminate and Monitor the Risk

\section{Identify the Risk}

The first step this is to identify a list of hazards associated with the pilotage and towage with special focus on the possibility of pilot error. Common methods of Hazid and Hazop may be used to identify the hazards.

\section{Analyse the Risk}

There are several risk analysis tools like Failure Mode and Effects Analysis (FMEA), Fault Tree Analysis, and Event Tree Analysis may also be used to analyse the risk.

\section{Evaluate or Rank the Risk}

Quantifying and ranking all the risks, the selecting those higher risks to work on them. 
Table 2: Risk Matric

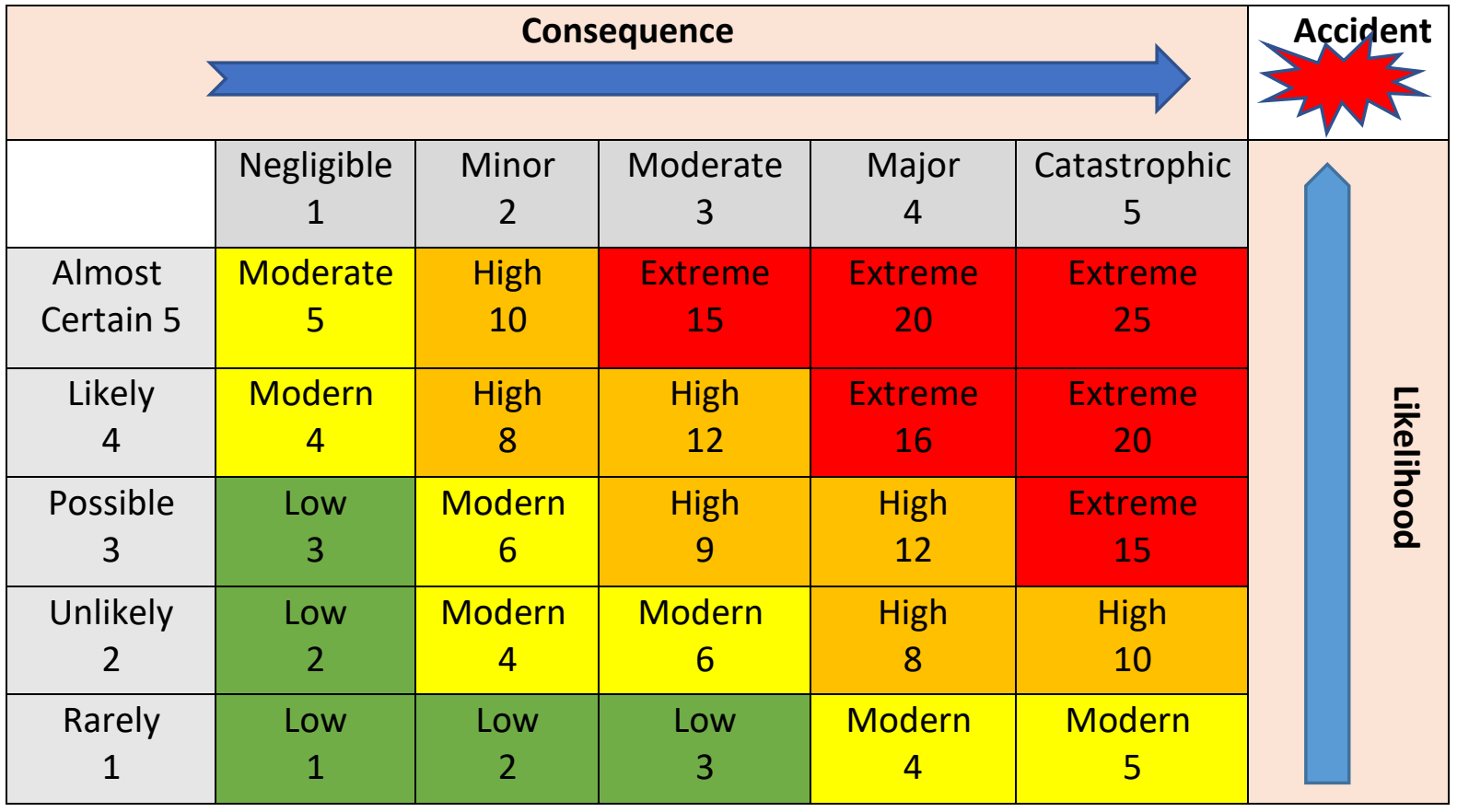

\section{Treat the Risk}

Upon ranking and selecting those higher risks, consult the experts or use a simulator to find the solutions to those risks identified. There are several ways to treat the risk. One can control and reduce the risk by quality control; frequent audit; compliance with regulations; more training; regular maintenance; improvement on Standard of Operation (SOP) or introduction of new technologies.

\section{Eliminate and Monitor the Risk}

The ultimatum of eliminating all risks and threats on pilotage is necessary to elevate the operation standard same as aviation industry. A proper monitoring system should also be introduced.

\section{Findings}

From the literature reviews, the best Generic Model for the Pilot Reliability Index (MPRI) done by Atiyah (2019) as shown in Table 3: 
Table 3: Generic Model for the Pilot Reliability Index (MPRI)

\begin{tabular}{|c|c|c|}
\hline Level 1 & Level 2 & Level 3 \\
\hline Goal & Shaping Factors & Sub Factors \\
\hline \multirow{13}{*}{ 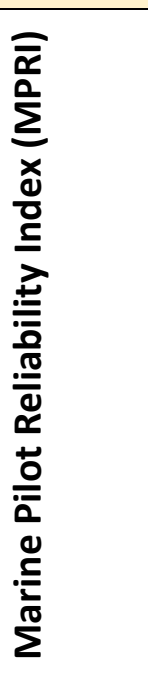 } & \multirow{3}{*}{$\begin{array}{r}\text { Technical Proficiency } \\
\text { (TP) }\end{array}$} & Pilot License (QPL) \\
\hline & & Special Training (ST) \\
\hline & & Working Experiences (WEx) \\
\hline & \multirow{3}{*}{$\begin{array}{r}\text { Personal Fatigue } \\
(\mathrm{PF})\end{array}$} & Working Hours (WH) \\
\hline & & Work Stress (WS) \\
\hline & & Work Environment (WEnv) \\
\hline & \multirow{4}{*}{$\begin{array}{r}\text { Non-Technical Skill } \\
\text { (NTS) }\end{array}$} & Decision Making (DM) \\
\hline & & Situational Awareness (SA) \\
\hline & & Communication Skill (CS) \\
\hline & & Teamwork and Leadership (T\&L) \\
\hline & \multirow{3}{*}{$\begin{array}{r}\text { Fitness \& Strength } \\
(\text { F\&S) }\end{array}$} & Operator Age (OA) \\
\hline & & Health Issue (HI) \\
\hline & & Body Strength (BS) \\
\hline
\end{tabular}

\section{The Improvised MPRI}

From the literature reviews, pilot error can be further enhanced if the shaping factors are to be improvised. This is especially true with the Advancement of Technology (AT) and Continuous Professional Development (CPD). One may argue that they are part of the Pilot License for the Continuous Professional Development and Advancement of Technology and that this could be used as part of the special training. Since it is not a mandatory requirement on CPD and it is very costly to have simulation training. Therefore, it is not surprised to note that many pilots who are operating privately or from small pilotage company have not been undergoing their CPD for years.

In 2002, IMO issues the Formal Safety Assessment (FSA) and Human Risk Analysis (HRA). By combining the MPRI and the IMO's FSA and HRA, the new improvised MPRI will be able to eliminate all operation risks or accidents. The following is the improvised MPRI:

A more holistic application of improvised MPRI can only be achieve if we include the Human Error Analysis (HRA) or Pilot Error Analysis. They are other methodologies available in the market. i.e. Technique for Human Error Rate Production (THERP) or Human Error Assessment and Reduction Technique (HEART). 
Table 4: Improvised MPRI

\begin{tabular}{|c|c|c|}
\hline Level 1 & Level 2 & Level 3 \\
\hline Goal & Shaping Factors & Sub Factors \\
\hline \multirow{20}{*}{ 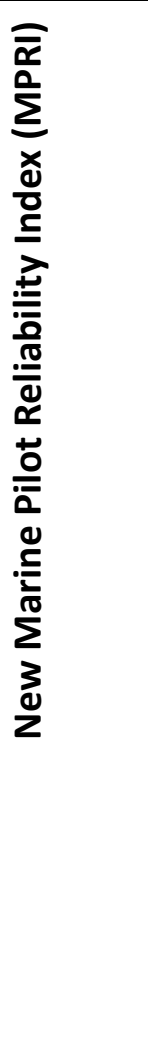 } & \multirow{5}{*}{$\begin{array}{r}\text { Technical Proficiency } \\
\text { (TP) }\end{array}$} & Pilot License (QPL) \\
\hline & & Special Training (ST) \\
\hline & & Working Experiences (WEx) \\
\hline & & Advancement of Technology (AT) \\
\hline & & Continuous Professional Development (CPD) \\
\hline & \multirow{3}{*}{$\begin{array}{r}\text { Personal Fatigue } \\
\text { (PF) }\end{array}$} & Working Hours (WH) \\
\hline & & Work Stress (WS) \\
\hline & & Work Environment (WEnv) \\
\hline & \multirow{4}{*}{$\begin{array}{r}\text { Non-Technical Skill } \\
\text { (NTS) }\end{array}$} & Decision Making (DM) \\
\hline & & Situational Awareness (SA) \\
\hline & & Communication Skill (CS) \\
\hline & & Teamwork and Leadership (T\&L) \\
\hline & \multirow{4}{*}{$\begin{array}{r}\text { Fitness \& Strength } \\
(F \& S)\end{array}$} & Operator Age (OA) \\
\hline & & Health Issue (HI) \\
\hline & & Mental Strength (MS) \\
\hline & & Body Strength (BS) \\
\hline & \multirow{4}{*}{$\begin{array}{r}\text { Risk Assessment \& } \\
\text { Mitigation } \\
(\text { RAM) }\end{array}$} & Risk Identification (RI) \\
\hline & & Risk Analysis (RA) \\
\hline & & Risk Evaluation \& Ranking (RER) \\
\hline & & Risk Mitigation (RM) \\
\hline
\end{tabular}

\section{Technology Advancement}

In term of the technical proficiency, another two (2) sub factors needed to be added to it. As the pilots needed to deal with the technology advancement of shipboard equipment, new types of pilotages or towage operation. On the development of new technologies, Xi. et al, (2017) highlighted that the emergence of complex systems such as nuclear plant, Ultra Large Container Vessel (ULCV) and introduction of Autonomous Ship. The smart un-manned ship that using lot of intelligence information technologies making the consequences of accidents more serious. Therefore, it is very important for the pilots to keep pace with the new development of technologies.

\section{Continuous Professional Development (CPD)}

Australasian Marine Pilots Institute (AMPI) defined the pilot CPD as:

This is to ensure that related port and shipping industries are provided with marine pilotage services that are of the highest standard. A measure of this is achieved through recognition of points in professional evaluation, ongoing skills and knowledge development, and ongoing training in emergency pilotage.

CPD is rather a new frontier for mariners or pilots and lifelong learning on the subject matters that are related to pilotage should be regulated by all the Competent Authorities. Professionals like pharmacists, medical practitioners, engineers and lawyers have implemented CPD and progressed very well in monitoring their professions.

The CPD will ensure continuous acquiring of new knowledge and development related to pilotage and port industries. The existing IMO Resolution A. 960 "Recommendations on 
training and certification, and operational procedures for maritime pilots other than deep sea pilots" (2004) should be reviewed and formulate a new universal CPD system for the pilots.

\section{Risk Assessment \& Mitigation}

The Pilotage authorities, organizations or individual pilots should conduct a detailed risk assessment of their daily operational task. They should follow the guidelines as per IMO's FSA on their existing pilotage task or new task. However, there are other risk identification methodologies can be used. Detailed qualitative risk analysis should be done to identify and to ascertain all pilotage and towage risks. Then, possible pilot risk or pilot errors may be reduced or eliminated.

From most the risk assessments and root cause analysis of any accident, personal fatigue (PF) is well known problem and a serious cause of ship accidents Beşikçi (2015). This problem can easily be eliminated if the organization or pilot could consider to re-schedule the working roster or recruit more pilots. Sufficient rest for pilots or following the proper SOP on pilot deployment must be implemented so that personal fatigue can be eliminated.

\section{Conclusion}

From the various literature review papers, we have found ways to improve the MPRI. This paper demonstrates shaping factors like Technologies Advancement; Continuous Professional Development and conducting Risk Assessment or using of MPRI and IMO's FSA \& HRA (2002) will derive more accurate Marine Pilot Reliability Index. The additional shaping factors ensure better result in the Pilot Reliability and to reduce or eliminate accident.

\section{References}

Atiyah, A. A. (2019). Reliability Analysis of Marine Pilots Using Advanced Decision-Making Methods. Liverpool John Moores University (United Kingdom).

Aneziris, O. N., Papazoglou, I. A., Konstantinidou, M., \& Nivolianitou, Z. (2014). Integrated risk assessment for LNG terminals. Journal of Loss Prevention in the Process Industries, 28, 23-35.

Akyuz, E. (2016). Quantitative human error assessment during abandon ship procedures in maritime transportation. Ocean engineering, 120, 21-29.

Aven T. (2016). Risk assessment and risk management: Review of recent advances on their foundation. European Journal of Operational Research, 253, 1-13.

Badida, P., Balasubramaniam, Y., \& Jayaprakash, J. (2019). Risk evaluation of oil and natural gas pipelines due to natural hazards using fuzzy fault tree analysis. Journal of Natural Gas Science and Engineering, 66, 284-292.

Ballesio, J., Patel, H., Revenga, A., \& Rynn, P. (2009). Risk assessment and technology qualification process for offshore LNG pipelines. In: Offshore Technology Conference, Houston, Texas, USA, 4-7 May. pp. 1-9.

Baykasoğlu, A., \& Gölcük, I. (2017). Comprehensive fuzzy FMEA model: A case study of ERP Implementation risks. Implementation risks. Operational Research, 1-32.

Brandon, J. B., Chang, E. H., Witry, M. J., Garza, O. W., \& Trewet, C. B. (2012). Pilot evaluation of a continuing professional development tool for developing leadership skills. Research in Social and Administrative Pharmacy, 9(2), 222-229.

Bushra, K. B., Khan, F., Veitch, B., \& Yang, M. (2017). An operational risk analysis tool to analyse marine transportation in Arctic waters. Reliability Engineering \& System Safety, 169, 485-502. 
Chan, S. R., Hamid, N. A., \& Mokhtar, K. (2016). A theoretical review of human error in maritime accidents. Advanced Science Letters, 22(9), 2109-2112.

Cordon, J. R., Mestre, J. M., \& Walliser, J. (2016). Human factors in seafaring: The role of situation awareness. Safety science, 93, 256-265.

Cook, T. (1980). Human factors studies of the working hours of UK ship's pilots 1. A field study of fatigue. Appl Ergon 1980; 11: 85-92.

Darbra, R. M., Crawford, J. F. E., Haley, C. W., \& Morrison, R. J. (2007). Safety culture and hazard risk perception of Australian and New Zealand maritime pilots. Marine policy, 31(6), 736-745.

Ferguson, S. A., Lamond, N., Kandelaars, K., Jay, S. M., \& Dawson, D. (2008). The impact of short, irregular sleep opportunities at sea on the alertness of marine pilots working extended hours. Chronobiology international, 25(2-3), 399-411.

Gucma, S., \& Zalewski, P. (2019). Optimization of fairway design parameters: Systematic approach to manoeuvring safety. International Journal of Naval Architecture and Ocean Engineering, 12, 129-145.

Hong-Bin, W. (2018). Study of ship piloting risk aversion based on human reliability analysis. PSAM 2018 - Probabilistic Safety Assessment and Management PSAM 14, September 2018, Los Angeles, CA.

Illkyun I., Shin, D., \& Jeong, J. (2018). Components for smart autonomous ship architecture based on intelligent information technology. Procedia computer science, 134, 91-98.

Mullai, A., \& Paulsson, U. (2011). A grounded theory model for analysis of marine accidents. Accident Analysis \& Prevention, 43(4), 1590-1603.

Lim, J. K. (2018). An analysis of the need for a pilot civil liability restriction system in South Korea for marine safety. World Maritime University.

Luana C. M., \& Chambers, T. P. (2015). Factors affecting maritime pilots' health and wellbeing: A systematic review. International maritime health, 66(4), 220-232.

Suoma N. K. (2018). An analysis of the maritime pilot training and certification: a comparative study between Denmark and Namibia. World Maritime University.

Suzanna, R. C. S. R., Hamid, N. A., \& Mokhtar, K. (2016). A theoretical review of human error in maritime accidents. Advanced Science Letters, 22(9), 2109-2112.

Xavier B., Daamen, W., Vellinga, T., \& Hoogendoorn, S. P. (2018). State-of-the-art of port simulation models for risk and capacity assessment based on the vessel navigational behaviour through the nautical infrastructure. Journal of Traffic and Transportation Engineering (English Edition), 5(5), 335-347.

Xi, Y. T., Yang, Z. L., Fang, Q. G., Chen, W. J., \& Wang, J. (2017). A new hybrid approach to human error probability quantification-applications in maritime operations. Ocean Engineering, 138, 45-54.

Varela, J. M., \& Guedes Soares, C. (2016). Geometry and visual realism of ship models for digital ship bridge simulators. Proceedings of the Institution of Mechanical Engineers, Part M: Journal of Engineering for the Maritime Environment, 231(1), 329-341.

Zhang, J., Teixeira, Â. P., Soares, C. G., \& Yan, X. (2018). Quantitative assessment of collision risk influence factors in the Tianjin port. Safety science, 110, 363-371. 